\title{
ILLEGAL MIGRANTS AND TERRORIST THREATS IN WESTERN COUNTRIES AFTER SEPTEMBER 11, 2001: PERCEPTIONS AND REALITY
}

\begin{abstract}
This article provides a preliminary assessment of the relationships between illegal migration, jihadist terrorism, and the perceptions of migrants by citizens of Western countries. The research was based on officially available data on terrorism provided by Europol and the results of surveys conducted by the Pew Research Centre or IPSOS. Assessments of the migration-terrorism nexus used a quantitative and qualitative analysis method, as well as a document and scientific literature research method. The results of most studies on the links between terrorism and migration indicate that there are insufficient correlations between these phenomena. However, the issue of the vulnerability of second and third-generation migrants to radicalization is significant. Vigilance on this issue is important in order to maintain adequate security for those who could become victims of potential terrorist attacks.
\end{abstract}

Keywords: illegal migration, terrorism, security, European Union, United States.

\section{INTRODUCTION}

A significant number of deaths resulted from the terrorist attacks carried out in the United States on September 11, 2001. These attacks have influenced the perception of migrants, mainly from countries with large Muslim populations. A 2016 IPSOS survey found that a large proportion of the US and the UK citizens considered migrants to be potential terrorists. Most of citizens of the European Union countries also feared the terrorist threat from migrants. The exceptions were Spanish citizens. The views of citizens of European countries on the potential threat from migrants depended on political views. The terrorist attacks carried out in the United States in 2001 had also a significant impact on public opinion thereafter regarding Donald Trump's intended entry ban.

The claim about the link between terrorism and migration has prompted researchers to undertake studies to prove the validity of this formulation. The example of the terrorist attacks in Paris in 2015 has often served as an argument supporting the thesis that there is a direct link between illegal migration and terrorism. However, most studies did not show such a correlation between migration and terrorism. Instead, the relationship between foreign-born population growth and Islamist terrorist activity in the United States was significant. The number of terrorist attacks bearing the hallmarks of Islamic terrorism

\footnotetext{
${ }^{1}$ Marta Hołdyńska, MSc, University of Natural Sciences and Humanities in Siedlce, Faculty of Social Sciences, Institute of Security Studies, 39 Zytnia St., 08-110 Siedlce; e-mail: martaholdynska@gmail.com. ORCID: 0000-0003-0513-1643.
} 
increased in 2001, influenced by the terrorist attacks on the World Trade Center. While the largest population of Muslims came from the Asia-Pacific regions, the number of Muslims migrating to the United States increased in 2012. There was a general view that Islamists were behind most terrorist attacks, but this was only a small proportion of all attacks. However, the issue of the vulnerability of second and third generation migrants to radicalisation, due to factors such as discrimination, cultural marginalisation or religious fundamentalism was important.

The change observed after 2001 in the way migrants are perceived by the citizens of Europe and the United States, due to potential links with terrorist attacks, makes this issue directly related to the area of research interests of the security sciences. This subject, due to its sensitive nature and the ease of making an biased assessment, has not been taken up too often in the scientific literature so far. This article attempts a preliminary assessment of public perception of the relationship between illegal migration and jihadist terrorism. Assessments of public perceptions of the links between migration and jihadist terrorism used a quantitative and qualitative analysis method, as well as a document and scientific literature research method. Officially available data on terrorism provided by Europol and results of studies on migration and terrorism conducted by Pew Research Centre or IPSOS provided background information for further discussion on interrelationships between illegal migration and the terrorist threat in the Western countries.

A review of research findings on the public debate surrounding the topic of migrants' links to terrorism provides a starting point for further considerations related to assessing the perceptions of illegal migrants by citizens of the United States and the European Union after the terrorist attacks of September 11, 2001. The second part of the article contains an analysis of research results devoted to the problem of links between illegal migration and jihadist terrorism. In the further part of the article there is an attempt to verify the stereotypes of public opinion on the links between illegal migration and jihadist terrorism after 11 September 2001, based on an earlier analysis of the results of research on this issue.

\section{PUBLIC DEBATE ON THE LINKS BETWEEN ILLEGAL MIGRATION AND JIHADIST TERRORISM}

The consequence of the terrorist attacks of September 11, 2001 was a significant loss of life. About 3,000 people were killed with about 2,000 of them in the terrorist attacks that took place on September 11, 2001 (Shamlan, 2018). This situation have greatly influenced the way migrants were perceived by citizens of the European Union and the United States during the migration crisis. These countries have significantly tightened immigration laws and introduced policies that put pressure on migrants to integrate into host countries. Restrictions on migrants' rights such as surveillance and sanctions have been introduced. These actions were motivated, among other things, out of concern that the more foreigners live in a country the higher is the risk of terrorist attacks (CESIFO, 2017). Imigration crisis invigorated public debate on negative effects of migration. Migrants were often blamed for the problems in the labour market and access to social benefits. Public debate pointed more frequently at difficulties in assimilation or integration of immigrants, threats to national identity, the growth of organised crime and terrorism (Raczyński, 2015). Based on a 2016 IPSOS survey, it was revealed that 72 percent of UK citizens considered migrants as potential terrorists, who intended to carry out an attack in their country. 77 percent of Americans were as likely to say the same as UK citizens (IPSOS 2016). The situation was 
similar in other European countries. Most of European citizens feared a terrorist threat from migrants. According to a 2016 opinion poll compiled by the Pew Research Centre, British respondents were 52 percent likely to say that an influx of migrants could increase the threat of terrorism, while 41 percent of respondents thought there was no correlation between mass migration and terrorist attacks. In other EU countries, a large proportion of people feared threats from migrants. Among them were countries such as Hungary and Poland, where terrorist attacks were feared by 76 percent and 71 percent of citizens respectively. As an example of countries where the percentage of people fearing terrorist attacks from migrants was relatively high, we can mention also Germany (61 percent), the Netherlands (61 percent) and Italy (60 percent). A different view was held by Spanish respondents. Only 40 percent of them were concerned about terrorist attacks by migrants (Wilke, Stokes, Kimmons, 2016).

It is also worth noting an important fact about the views of citizens of the European Union countries on the potential threat from migrants. The views and assessments depended largely on political views. The situation on the United Kingdom may serve as an illustrative example of the situation. In 201687 percent of the Independence Party's supporters said that migrants could contribute to the risk of terrorist threats on European soil. The situation was different for the supporters of the Labour Party, only 39 percent of whom were concerned about increasing terrorist threat. The Conservative Party supporters held the most extreme views, with 60 percent of them believing that terrorism would increase due to the influx of migrants to Europe (Wilke et al. 2016).

The terrorist attacks of September 11, 2001 were also reflected in the public's opinion of President Donald Trump's 2017 ban on people entering the United States. A significant number of Americans have expressed support for a ban on six countries with a majority Muslim population. Overall, about 60 percent of respondents expressed support for the ban and only 28 percent were against it. However, it is worth noting that the majority of the plan's supporters, 84 percent, were also supporters of the Republican Party. Slightly less extreme opinions on banning entry to the US for Muslims, circulated among non-partisans. 56 percent of non-partisans supported the ban, while 30 percent opposed it. The most divided opinions on banning Muslims were shown by the results of surveys conducted among supporters of the Democratic Party. 46 percent of such respondents were against the ban, while 41 percent supported Donald Trump's idea (Politico, 2017).

In conclusion, the terrorist attacks of September 11, 2001 have greatly affected the perceptions of migrants by citizens of the European Union and the United States. Americans and citizens of European Union countries were concerned that migrants could significantly contribute to the risk of terrorist attacks. The views of the US and the EU citizens on the occurrence of a potential threat from migrants were highly dependent on political views. The supporters of conservative and right wing parties were more concerned about increased terrorist threat caused by migrants that the supporters of liberal and left wing parties.

\section{THE LINK BETWEEN MASS MIGRATION AND THE NUMBER OF TERRORIST ACTS AFTER 2001}

The emergence of the claim in the International Organization for Migration's report that terrorism, due to its transnational nature, and migration are linked has prompted researchers to undertake research to examine the issue in more detail (IOM, 2010). Some researchers have argued that terrorism and migration are related and that it would be significant to use 
migration as a tool to combat terrorism. The rationale for this claim was to emphasize the importance of a well-functioning migration system to serve as the most important tool in the fight against terrorism (Krikorian, 2002).

The terrorist attacks in Paris in 2015 have often been used as an argument to support the thesis that there is a direct link between migration and terrorism because some of the terrorists involved in the attack entered Europe with the influx of migrants (Kis-Benedek, 2016). Other researchers, however, disagreed with the claim that migration and terrorism are related. As an example, a report published by the United Nations Rapporteur on Counter-Terrorism and Human Rights makes clear that there is no evidence to support a link between migration and terrorism (OHCHR, 2016). Another argument to negate the link between migration and terrorism was the claim about the global economic market on which the power of the West was mainly based. Western adoption of stricter migration procedures could be detrimental to the economic market and lead to economic isolation (Kerwin, 2005).

Analyzing the problem of the relationship between migration and terrorism, it is worth using studies that show the relationship between these phenomena. Most studies do not find a correlation between migration and terrorism. The relationship between terrorist attacks and migration flows in the United States between 2000 and 2016 was weak. The situation was similar in the United Kingdoom, where in the same years as in the United States, the influx of migrants was weakly correlated and the number of terrorist attacks decreased significantly after 2001. It is worth nothing that during that period, there was a renewed increase in terrorist attacks in the UK for which the Northern Ireland dissidents were responsible (Shamlan, 2018).

The correlation between migration flows and deaths from terrorist attacks in the United States between 2000 and 2016 also shows no significant relationship. However, it is worth mentioning that in the history of the United States, in 2001, a record number of deaths were registered as a result of terrorist attacks on the World Trade Center. Nevertheless, the overall death toll from terrorist attacks between 2000 and 2016 was not significant. The situation regarding the relationship between illegal migration and the number of deaths from terrorist attacks in the UK between 2000 and 2016 also showed no significant correlation (Shamlan, 2018).

However, it is worth mentioning that there is a correlation between foreign-born population growth and Islamist terrorist activity in the United States. The number of terrorist attacks bearing the hallmarks of Islamic terrorism increased in 2001, then dropped to zero and began to increase again in 2012. Between 2000 and 2011, there were no significant correlations between foreign-born population growth and Islamist terrorist activity. Instead, the correlation between 2012 and 2016 was significant, meaning that the increase in the foreign-born population during those years could be responsible for about 87 percent of Islamic terrorist attacks. The situation was different in the UK where no link was observed between the increase in the foreign-born population and Islamist terrorist activities within the UK (Shamlan, 2018).

In summary, the emergence of the claim about terrorism and its transnational nature and its relationship with migration has prompted researchers to undertake research to analyse this problem in more detail. A number of researchers have argued that terrorism and migration are related, but others have disagreed with this assumption. Most studies did not show a direct relationship between migration and terrorism. The United States recorded a significant number of deaths from terrorist attacks in 2001 , but the overall number of 
deaths between 2000 and 2016 did not show a significant correlation with migration. However, there was a correlation between the increase in foreign-born population and Islamist terrorist activity in the United States. The number of terrorist attacks bearing the hallmarks of Islamic terrorism increased in 2001. Another significant increase in terrorist attacks occurred again in 2012 and continued consecutively until 2016.

\section{THE IMPACT OF STEREOTYPES ON SOCIETY'S PERCEPTION OF MIGRANTS AFTER 2001}

Assessing the religion of migrants based on their country of origin is difficult. The largest population of Muslims comes from the Asia-Pacific regions. (Desilver, Masci, 2017). Studies estimate that the number of Muslims migrating to the United States increased from about 50,000 in 1992 to 100,000 in 2012. There were, some annual differences in the number of Muslim migrants, but overall an increase in the number of migrants to the United States between 1992 and 2012 was observed (Pew Research Centre, 2013). In 2017, research estimated the number of Muslims at about 3 million or 1.1 percent of the US population (Pew Research Centre, 2018). In contrast, the 2011 census showed that the number of Muslims in the UK was 4.8 percent of the population of England and Wales (The Muslim Council of Britain, 2015). However, it is worth noting that Islamists who are believed to be behind the majority of terrorist attacks were responsible only for 1.74 percent of all terrorist attacks in the United Kingdom and 10.5 percent of all terrorist attacks in the United States (Shamlan, 2018). Jihadist terrorist attacks were conducted mainly due to a mentality that rejected democracy on religious grounds. The medieval Crusades were equated with a situation, in which it was claimed that Sunni Islam was facing a "crusader alliance" consisting of Shiites, Christians and Jews (TESAT, 2017). Jihadist terrorist attacks caught public attention because of their focus on inflicting human losses. Overall, jihadist terrorist attacks resulted in 97.8 percent of deaths of all terrorist attacks in recent two decades. However, this number includes the 9/11 fatalities, which account for nearly 95 percent of the deaths from jihadist terrorist attacks. Given the high death toll from jihadist terrorist attacks, counter-terrorism vigilance is important, but the stigmatisation of migrants arriving in the Western countries and the stereotypes created by politicians and the media must be avoided. It is also worth noting that the findings of most studies on the jihadist-migration nexus suggest that there are insufficient correlations between the phenomena and that there is no concrete evidence to influence how migrants are perceived.

Evidence that migrants should not be seen as increasing the risk of terrorism prompts consideration of migrants' exposure to transnational terrorist organisations. Factors such as social environment, discrimination, identity problems, economic conditions, cultural marginalisation and the influence of the country of origin mean that migrants can often become victims of radicalisation. Radicalization is the phenomenon of people adopting ideas that can lead to terrorist attacks. The basis of radicalization is often religious fundamentalism, but it is often the case that this is not the only factor influencing radicalization. It is not uncommon for this process to be influenced by frustration with one's own life and the country's domestic and foreign policies. People who often experience discrimination and a sense of loss of identity, from marginalized groups are more prone to radicalization Additionally, Western Europe's involvement in conflict zones such as Afghanistan and Syria also contributes to radicalization, especially of migrant communities (European Parliament, 2021). One can observe the phenomenon of diaspora communities 
acting against their adopted homelands. Diasporas can also act as support for terrorist objectives by raising funds from organized crime practices, recruiting new candidates and acquiring weapons. Terrorists who come from Muslim diasporas can be divided into three categories. The first is those who have converted to Islam. Two sub-categories can be distinguished here such as "hardcore" or long-term jihadists trained in camps and "walkins" or self-radicalized jihadists. These are individuals who have joined the jihadist movement. The second group of terrorists hailing from Muslim diasporas are those who have undergone a failed second-generation assimilation process. Such descendants of immigrants are particularly dangerous because they are difficult to identify. Additionally, so-called "homegrown terrorists" have knowledge of potential targets for terrorist attacks, speak languages, and are able to move freely around the world (Kobzarska-Bar, 2014). The third group were first-generation migrants who could not fit into the new society and lived on the margins (Hoffman, 2007). It is also worth noting that currently radicalization processes are mainly based on social networks that allow people to join groups that incite violence. The Internet is one of the most significant channels through which extremist views are preached and individuals are recruited for terrorism-related activities. In addition, restrictions on travel and physical encounters caused by the COVID-19 pandemic, may have led to increased use of online external content and networking (TESAT, 2021).

In summary, after the terrorist attacks of September 11, 2001, the public's views of Western countries about migrants coming from Muslim countries often referred incorrectly to the facts of the situation. The stereotypes created by the media and politicians were not really reflected in reality, which is precisely confirmed by numerous studies conducted on the relationship between migration and terrorism. The terrorist attacks were mainly due to jihadist religious views. The misjudgement of migrants and the attribution of blame for terrorist attacks to this group as a whole prompts us to analyse the problem from a different perspective. Migrants have often, through factors such as cultural marginalization and discrimination, fallen prey to transnational terrorist organizations. Western Europe's involvement in the conflict with Afghanistan and Syria further contributed to the vulnerability of migrant communities to radicalization. It was not uncommon for terrorists in Western European countries to come from diasporas. These included second-generation migrants who had undergone an unsuccessful assimilation process and first-generation migrants unable to fit into Western societies. Nowadays, the Internet is one of the main channels that foster radicalization processes. Restrictions on physical encounters due to the COVID-19 pandemic have led to intensifying online terrorist related activities.

\section{SUMMARY}

The terrorist attacks that took place on September 11, 2001 resulted in a significant number of fatalities. Due to this event, the public perception of migrants coming mainly from Muslim countries has changed in most of the Western countries. Numerous studies found that the US and the UK citizens considered migrants as potential terrorists. Citizens of the European Union countries were also concerned about the terrorist threat from migrants. The views of the EU citizens on the link between migration and terrorism were highly dependent on political views. The emergence of the claim that terrorism and migration are linked has prompted research to examine this issue in more detail. It must be noted that most of research did not find a direct correlation between migration and terrorism. Nonetheless, the relationship between foreign-born population growth and Islamist terrorist 
activity in the United States was significant. Second-generation migrants who went through an unsuccessful assimilation process were more prone to radicalization, and as a consequence they contributed to increase in terrorist threat in the Western countries. Factors such as religious fundamentalism, discrimination or frustration with their own lives and dissatisfaction with the policies of Western European countries also made second and third generation migrants more vulnerable to radicalisation. The results of most studies on the links between terrorism and migration show that there is not enough correlation between these phenomena, which is significant evidence that migrants should not be seen by society as the main source of terrorist attacks. At the same time it is important to pay attention to the problem of radicalization of subsequent generations of migrants and to take action to prevent this phenomenon, among others by improving assimilation policies. Such an approach may limit terrorist threat posed to Western societies by migrants who failed to assimilate.

\section{REFERENCES}

CESIFO Working Papers (2017). The Effect of Migration on Terror - Made at Home or Imported from Abroad? [Access: 1.09.2021]. Access on the internet: https://www. cesifo.org/en/publikationen/2017/working-paper/effect-migration-terror-made-home-orimported-abroad

Desilver, D, Masci, D. (2017). World's Muslim population more widespread than you might think. Pew Research Center [Access: 25.06.2021]. Access on the internet: http://www. pewresearch.org/fact-tank/2017/01/31/worlds-muslim-population-more-widespread-thanyou-might-think/

Europol (2017). European Union Terrorism Siuation and Trend Report (TE-SAT) [Access: 25.06.2021]. Access on the internet:https://www.europol.europa.eu/sites/default/files/ documents/tesat2017_0.pdf

- (2021). European Union Terrorism Siuation and Trend Report (TE-SAT) [Access: 16.07.2021]. Access on the internet: https://www.europol.europa.eu/sites/default/files/ documents/tesat_2021_0.pdf

European Parliament (2021). Radicalisation in the EU: what is it and how can it be prevented? [Access: 16.07.2021]. Access on the internet:https://www.europarl.europa.eu/news/pl/ headlines/security/20210121STO96105/radykalizacja-w-ue-czym-jest-i-jak-mozna-jejzapobiec

Hoffman, B. (2007). Radicalization, Terrorism, and Diasporas, RAND Corporation, 7-10 [Access: 16.07.2021]. Access on the internet: https://www.rand.org/content/dam/rand/ pubs/conf_proceedings/2007/RAND_CF229.pdf

IOM (2010). International Terrorism and Migration. IOM.

IPSOS (2016). Global Views on Immigration and the Refugee Crisis [Access: 26.06.2021]. Access on the internet:https://www.ipsos.com/en/global-views-immigration-and-refugeecrisis

Kerwin, D. (2005). The use and misuse of national security rationale in crafting US refugee and immigration policies. "International Journal of Refugee Law", Vol. 17, No. 4.

Kis-Benedek, J. (2016). Illegal immigration and terrorism. "Journal of Security and Sustainability Issues", Vol. 5. No. 4. 
Kobzarska-Bar B. (2014) Fundamentalizm religijny muzutmańskich organizacji terrorystycznych a stan zagrożenia w Europie. „Rocznik Bezpieczeństwa Międzynarodowego”, t. 8, $\mathrm{nr} 1$.

Krikorian, M. (2002). Asymmetrical Warfare and Immigration. "Centre of Immigration Studies", Vol. 1, No. 6.

OHCHR (2016). Refugees and terrorism: "No evidence of risk" New report by UN expert on counter terrorism [Access: 26.06.2021]. Access on the internet:http://www.ohchr.org/ EN/NewsEvents/Pages/DisplayNews.aspx?NewsID=20734

Pew Research Center (2013). The Religious Affiliation of U.S. Immigrants: Majority Christian, Rising Share of Other Faiths [Access: 27.06.2021]. Access on the internet: http://www. pewforum.org/2013/05/17/the-religious-affiliation-of-us-immigrants/

- (2018). Muslims in America: Immigrants and those born in U.S. see life differently in many ways [Access: 27.06.2021]. Access on the internet:http://www.pewforum.org/essay/ muslims-in-america-immigrants-and-those-born-in-u-s-see-life-differently-in-many-ways/

Politico (2017). Poll: Majority of voters back Trump travel ban [Access: 27.06.2021]. Access on the internet: https://www.politico.com/story/2017/07/05/trump-travel-ban-poll-voters240215

Raczyński, R. (2015). Wpływ migracji międzynarodowych na bezpieczeństwo wewnętrzne państw. „Bezpieczeństwo. Teoria i Praktyka”. Kwartalnik Krakowskiej Akademii im. Andrzeja Frycza Modrzewskiego, nr 2.

Shamlan, A. (2018). The Securitization of Immigration and its Correlation with Terrorism. Tallinn: University of Technology School of Business and Governance Department of Law.

The Muslim Council of Britain (2015). British Muslims in Numbers. "Muslim Council of Britain".

Wilke, R., Stokes, B., Kimmons, K. (2016). Europeans Fear Wave of Refugees Will Mean More Terrorism, Fewer Jobs. Pew Research Centre 1-44.

DOI: 10.7862/rz.2021.hss.20

The text was submitted to the editorial office: August 2021.

The text was accepted for publication: September 2021. 